\title{
Imagining Ro: On the social life of islets and the politics of islandography
}

\author{
Maria Hadjimichael \\ Department of Social and Political Sciences, University of Cyprus, Cyprus \\ mhadji46@ucy.ac.cy (corresponding author)
}

\section{Costas M. Constantinou}

Department of Social and Political Sciences, University of Cyprus, Cyprus constantinou.m.costas@ucy.ac.cy

\section{Marinos Papaioakeim}

Department of Social and Political Sciences, University of Cyprus, Cyprus mpapaioakeim@gmail.com

\begin{abstract}
This article engages the challenge of island history as caught in between national historiography and local life stories. It focuses on Ro, a Greek islet bordering Turkey that has been imagined and idealized as a space of national resistance and resilience. The article unpacks the grand national narrative that has been developed with regard to the heroic life story of a solitary woman living on the island. It utilizes local counter-narratives as well as the life stories of other solitary individuals who have periodically lived on the island. To that extent, the article aims, on the one hand, to sensitize as to the politics of islandography and, on the other, to highlight the importance of social history in challenging hegemonic or colonial narratives as well as reimagining island space.
\end{abstract}

Keywords: border islands, decoloniality, Greece, history, islands, Kastellorizo, national historiography

https://doi.org/10.24043/isj.123 • Received February 2020, accepted June 2020

(C) 2020-Institute of Island Studies, University of Prince Edward Island, Canada.

\section{Lady's island, nation's pride}

Nationally renowned and internationally unknown, the islet of Ro is part of the Kastellorizo complex, at the south-eastern-most archipelago of Greek islands, bordering Turkey (see Figures 1,2, and 3). Comprising a land area of 160 hectares, traditionally reserved for goatherding, Ro's social history is inextricably linked to that of the nearby bigger and populated island of Megisti (Kastellorizo) as well as the Turkish coast of Asia Minor. Geopolitically, it is located at the edge of the Greek sovereign space in the eastern Mediterranean Sea, around $120 \mathrm{~km}$ from the Greek island of Rhodes and just $5.5 \mathrm{~km}$ from the Turkish coast. Ro is a highly militarized islet, currently hosting a Greek army contingent - the only human 
inhabitants of the island - and access to it is restricted. The militarization of the island is strongly protested by Turkey, as it violates the Paris Treaty (1947) that demilitarized the Dodecanese islands, including the Kastellorizo complex. (See official rationale from the Turkish Ministry of Foreign Affairs at http://www.mfa.gov.tr/background-note-on-aegeandisputes.en.mfa). Greece justifies militarization as necessary due to the threat of Turkish violations of its Air Space as well as Turkish expansionism, especially following the invasion of the island of Cyprus in 1974. (See official rationale from the Greek Ministry of Foreign Affairs at https://www.mfa.gr/en/issues-of-greek-turkish-relations/relevant-documents/turkishclaims-regarding-the-demilitarization-of-islands-in-the-aegean-sea.html)

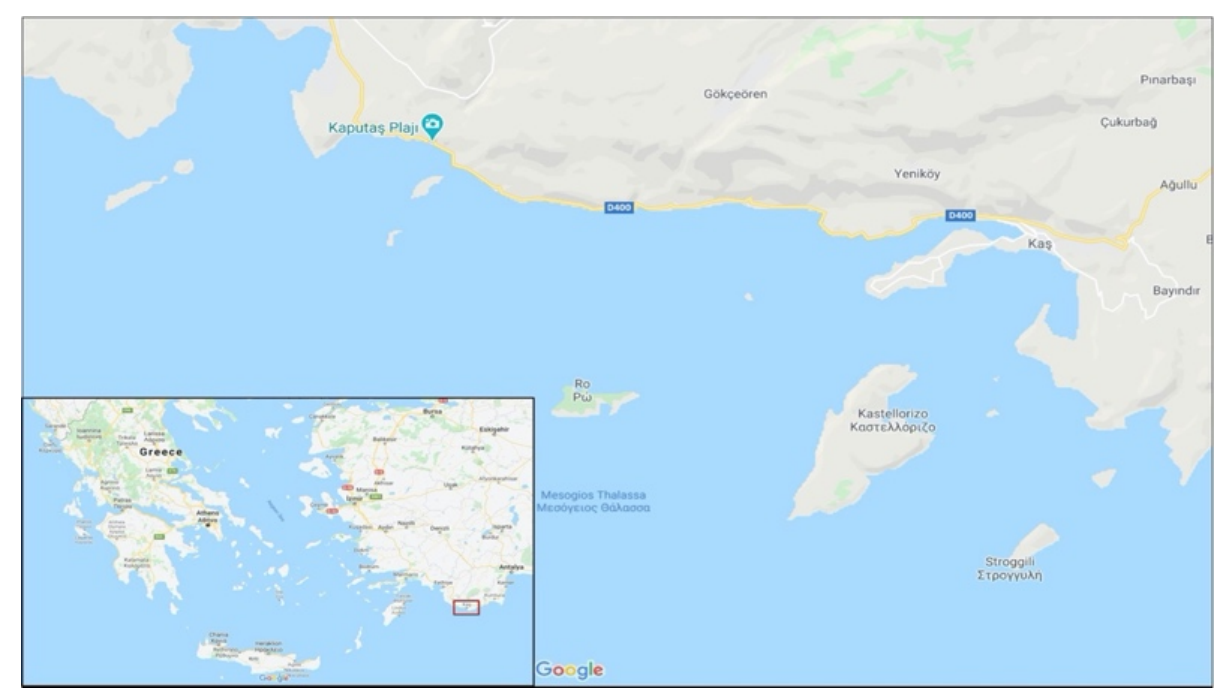

Figure 1: Map of the Kastellorizo island complex. Source: Adapted from Google Maps.

In the Greek national imaginary, Ro features as a heroic space. It has come to signify border resilience and valiant defiance, so brief visits to pay respects to this iconic islet are exceptionally allowed, if a local boat holding permission is chartered from Kastellorizo. It is a secular pilgrimage for nationalist aficionados and danger zone tourists. The pilgrimage is

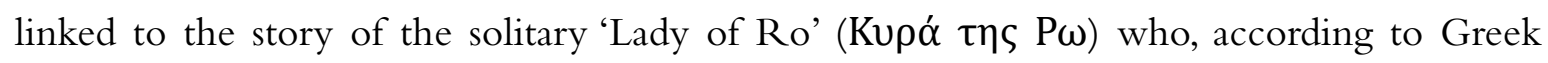
historiography, raised the Greek flag every sunrise and pulled it down at sunset for 40 years, up until her death in 1982 at the age of 89. The Lady is buried there.

But how does a small and isolated island become a national symbol? How can it be linked to a single person's biography? What alternative histories and narratives get sidelined in the process? How does one retrieve these stories and reconnect them to the biography of islands? Our research has been planned to respond to these questions.

Due to its current military status, conducting research in Ro is not easy and thus our first and only fieldtrip to the islet was choreographed. We visited it not as researchers but as tourists, wearing our bathing suits and sunglasses, bringing sun-cream and towels. As we entered the small cove of Ro, a loud song blasted from the speakers of the small charter boat that brought us there, introducing us to the national and historical 'reality' of the island.

My Lady from Kastellorizo, you who are great and brave, and part of the generation, who defied the snow.You were the beast of the sea, my dear Lady of Ro.You raised the pole of the flag, like a stout-hearted man... (Excerpt from a folk song written for the Lady of Ro) 


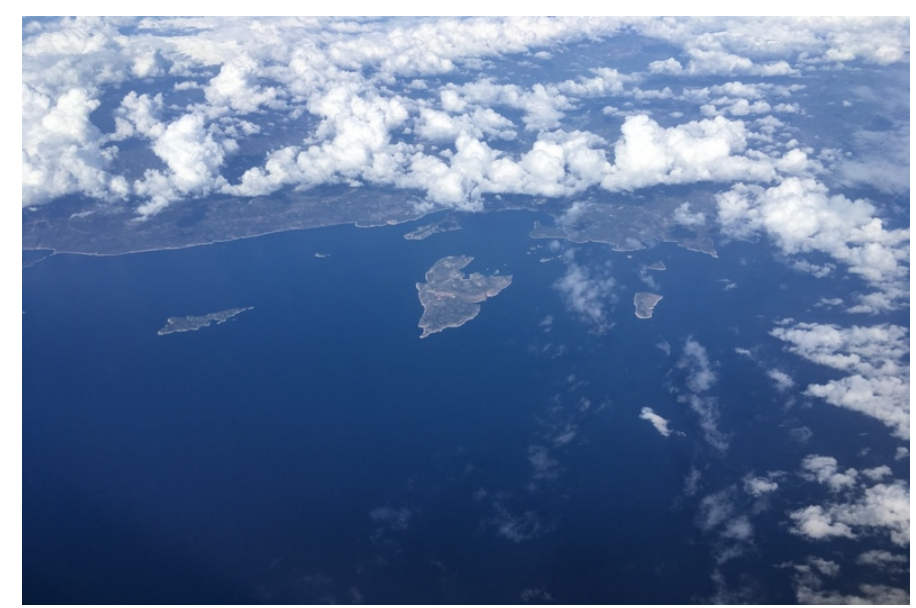

Figure 2: Aerial photo of the Kastellorizo island complex. Ro is the islet farthest to the left. Source: Costas M. Constantinou

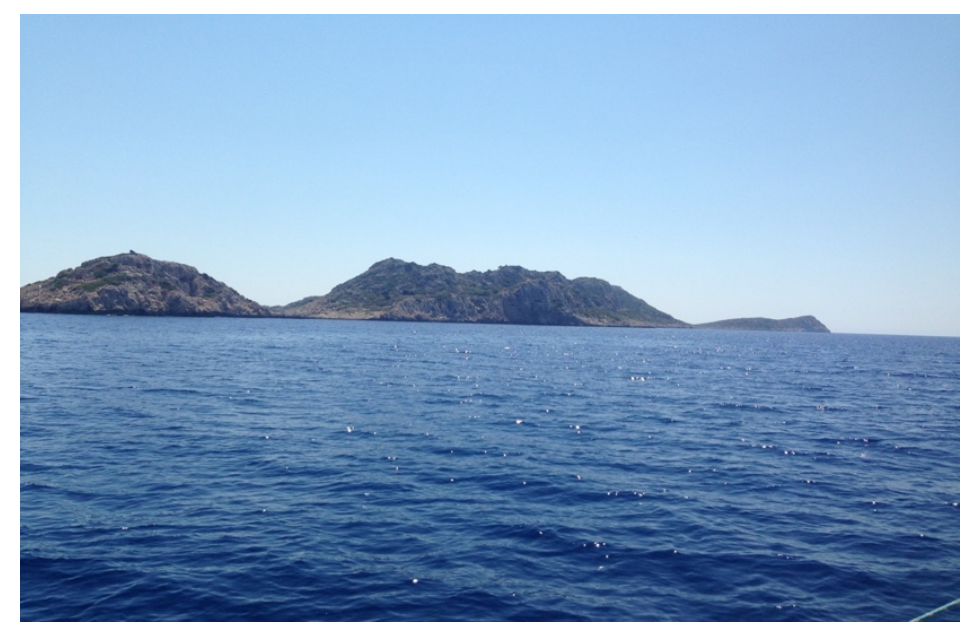

Figure 3: The islet of Ro approached from the northeast. Source: Costas M. Constantinou.

As we disembarked, a young soldier welcomed and informed us that since this is a military zone, we are only allowed on the island to visit the grave of the Lady of Ro, though, as a bonus, we could have a swim by the tiny sandy bay in the cove beside the grave (see Figures 4 and 5). We ceremoniously approached the grave, and the captain of the boat, a person in his $40 \mathrm{~s}$ from Kastellorizo, took his hat off as a sign of respect, put his arms on the metal frame encircling the grave, and bowed his head. We followed the protocol, visited the nearby chapel of Saint George, saw from a distance the small hut where the Lady of Ro lived (now part of the army barracks), and jumped into the sea. Truly a bizarre experience but also a typical visit given that, since the mid-1990s, this is how Ro is performed for and experienced by visitors.

In this article, we aim to go beyond the heroic story and political hagiography, that is, the charged and selective historiography of the island of Ro. We argue that this dominant narrative constructs a rather problematic - nationalist, masculinized, and militarized - account. Instead, we explore the social history of the island, following on the stories of the locals, chronicling other lives and alternative politics that inhabited this place. We also explore how the Lady of Ro story recently inspired a different theatrical play ( $\Sigma \kappa \alpha \rho \alpha \gamma \kappa \alpha \dot{\varsigma} \varsigma, 2017)$, a more reflexive and plural narrative, linked to the Greek economic crisis and human resilience. To that extent, the article develops a counter-narrative of Ro and its islandography. The 'hidden' 
and 'invisible' history of the islet was progressively revealed to us by conducting more detailed historical research, following on gaps and contradictions in the main narrative, and during our field research and interviews in Kastellorizo and Rhodes.

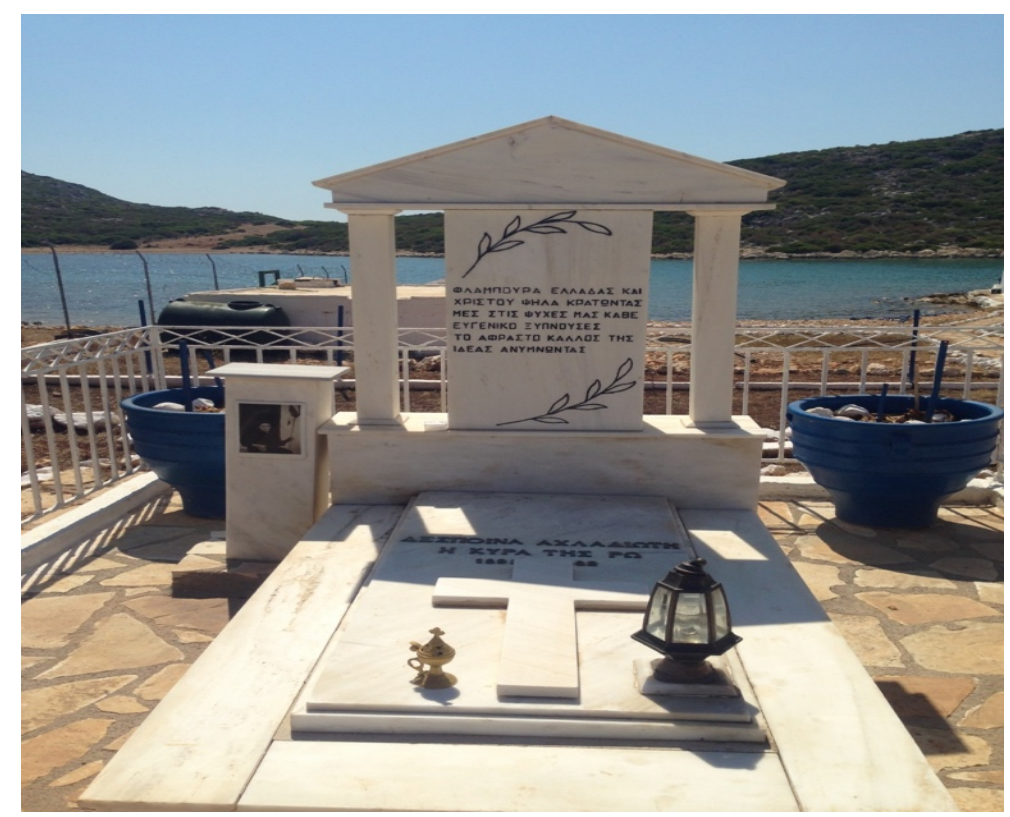

Figure 4: The tomb of the 'Lady of Ro' on the Islet of Ro. Source: Costas M. Constantinou.

During the fieldtrips, the first of which took place over two weeks in June 2017, and the other over ten days in June 2018, we conducted 10 interviews, and engaged in participatory observation in Kastellorizo. Our interviews were primarily based on the 'snowball' technique, meaning that our interviewees were selected following suggestions from people we met on the island or had already interviewed. Our aim was to interview people who had lived in Ro, or had a particular relationship with the islet, or knew and remembered the Lady of Ro. Though we had particular people in mind, or profiles of people we would like to interview based on our pre-fieldtrip desk study, being on Kastellorizo unfolded untold and unpublished (hi)stories which of course became essential for this paper. There were also two additional cases where a phone interview was required, with people who had previously lived in Kastellorizo and/or were involved in writing or performing biographies or literature about the Lady of Ro. Overall, we interviewed people who had lived in Ro, locals who lived at the same time as the Lady of Ro, officials at Kastellorizian institutions who had knowledge of Ro, as well as people who wrote literature or performed plays inspired by the Lady of Ro. Some of our interviewees met more than one of the aforementioned aspects. Biographical and autobiographical publications of people who lived in Ro were also used. We had the opportunity to visit the islet of Ro only once during our first visit since, in the lead up to our second visit, our trip to Ro was continuously cancelled on various pretexts that had to do, we assume, with the nature of our research.

In developing an alternative history of Ro, we build on the island studies literature and specifically engage the concept of islandography. This endeavour is therefore linked to debates explored throughout the field of island studies as well as postcolonial studies. Focusing on islands as living entities, with their own geological, ecological, as well as political and social histories, one can ask, what kind of identities do islands have and what are the factors which 
facilitate the construction of these identities? How do islands become islands, and how do they gain meaning and importance (and for whom, and for what purpose?). Given the size and isolation of Ro, we reflect on how uninhabited islands become a site of contestation between different actors for whom these spaces have different meanings and uses.

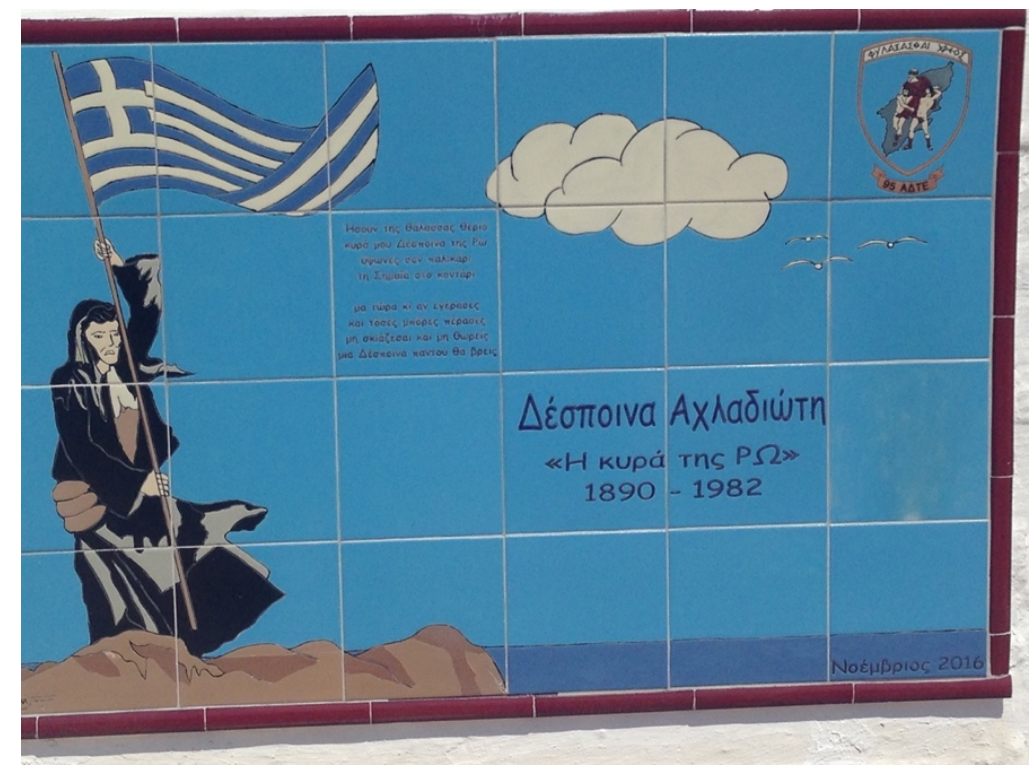

Figure 5: Iconic depiction of the Lady of Ro, next to her grave. Source: Costas M. Constantinou.

\section{Imagining islands, rewriting histories}

To explore an island as a "geographic personality" (Bennett, 1971, p. 40), one must appreciate different debates that have taken place over the years in the field of island studies. Starting from the basic question of "what is an island"/ "what does it mean for an entity to be an island" (Jędrusik, 2011), the debate has expanded to discussions on "how does one study islands" (Baldacchino, 2008), "what is their role in history" (local, national and global history; Dodds \& Royle, 2003), their relation with mainlands or bigger islands (Baldacchino, 2008; Nicholson, 2007), etcetera. Many discussions have also taken place around island identities (Bożętka, 2013; Gibbons, 2010; Stephens, 2013), as well as the way islands, and particularly smaller islands have been essentialised and romanticised (Gillis, 2001). In this section, we first explore debates around national historiographies as well as decolonial island histories in order to open up discussions on how different historiographies of the same space emerge through the cracks and how they are important in developing islandography.

\section{Between national historiography and decolonial islandography}

Baldacchino (2008, p. 37) states that to study islands on their own terms should be "a process of empowerment, a reclaiming of island histories and cultures, particularly for those island people which have endured decades of colonialism." Heeding Baldacchino's call to decolonize island histories, however, is not an easy task. At a minimum, it requires recognition that an island has been colonized, something that is not always evident, especially when it comes to 'small' and 'uninhabited' islands that are seen to be part of national space, whose centre is always 'elsewhere'. It also requires an understanding into the range and forms of colonization 
that have occurred and the conditions under which, if at all, meaningful and not just symbolic emancipation can be regained in the postcolony (Mbembe, 2001).

More specifically, islands have a geographic peculiarity that can directly impact on decolonization claims. On the one hand, they are unquestionably 'geographically separate'. And so, they meet the criterion of 'salt-water' colonialism vis-à-vis land continuity, i.e., with respect to the international law of self-determination as developed and contextualized in 1960 General Assembly Resolution 1541 (XV), where territorial, ethnic or cultural distinctiveness is invariably demanded (Trinidad, 2018, p. 12). On the other hand, the smaller or more sparsely populated an island is, the easier it is to be territorially linked to continental countries or major archipelagos. In short, small islands may be distinct and separate but can also be easily connected to larger territories through national history.

Reclaiming island histories thus depends on how far the 'salt water' frame will serve as a connective or partitive or separative. How far would it follow the dominant, metropolitan historiography, imperial or postcolonial, that views the history of the island as part of a wider national space and time, or seek to resist it? If the latter, to what extent can it utilize its less monumental, peripheral, or castaway biography to problematize or 'provincialize' metropolitan history (Chakrabarty, 2000)? The development of alternative and emancipatory forms of islandography is closely entangled with the postcolonial predicament of imagining beyond the Western-centric, formally recognized and now globalized, 'nation-state'.

Challenging the perennial thesis of the nation-state, Benedict Anderson (1983) argued for the need to come to terms with the institutional formation of the nation as an 'imagined community', sustained through such modern practices as cartography, the census, and the museum. Whilst acknowledging the value of revisioning the nation as a construct and performative, Partha Chatterjee (1993), however, thought it was equally important to reflect on the fragments of the nation, the 'subnational' and 'transnational' communities that also did a lot of imagining in parallel, or in opposition to, the institutional imagining. Chatterjee (1993, pp. 3-13) posed the pithy but pertinent question: "whose imagined community" must we valorize and what is at stake in valorizing one over another? What Chatterjee (1993, p. 5) raised as a predicament of postcolonial historiography speaks directly to the predicament of islandography, especially that of small, distant and sparsely populated islands:

History, as it would seem, has decreed that we in the postcolonial world shall only be perpetual consumers of modernity. Europe and the Americas, the only true subjects of history, have thought out on our behalf not only the script of colonial enlightenment and exploitation, but also that of our anticolonial resistance and postcolonial misery. Even our imaginations must remain forever colonized.

From this perspective, an alternative history of the nation, a history that tells the stories of its 'margins', 'minorities', 'outcasts', and other 'fragments' is valorized as a 'decolonization of imagination' that has become a major concern in postcolonial theorizing (Pieterse \& Parekh, 1995; wa Thiong'o, 1992). This is not a mere rejection or revision of the 'grand narratives' of the nation. It is also about the modes of thinking of the national and colonial experience. It concerns the forms of knowledge employed by modern forms of governance, the travelling, surveying and museological modalities that transform objects into historically significant artefacts that narrate the nation and its deeds (Cohn, 1996). It is also about the alternative 
'cultural' forms that count as 'legitimate knowledge' in writing island histories (Chakrabarty, 2000; Smith, 2013). From this perspective, the use of geopoetics has been proposed as a hermeneutic practice to study islands, and the way spatial 'knowledge' is produced and reproduced in the process of social and cultural change, grounding island representation on the set of localizing and particularizing constraints that act upon it (Balasopoulos, 2008).

The first wave of postcolonial theory, concentrated on the history of the subjugated and the subaltern, and how to speak on their behalf and/or make it possible for them to articulate their own stories (Morris, 2010; Spivak, 1999). This, however, concentrated on human history and classical colonialism, how a distinct community was subjected to the rule of a 'foreign' people. The second wave of postcolonial theory has looked more intensely on the colonization of life-worlds and habitats, the 'wild politics' and biocolonialisms of modern national and imperial governance (Gray \& Sheikh, 2018; Hawthorne, 2008; Opondo, 2015). Both revisionings are pertinent to our island of study. The first with regard to people living on the Ro 'border zone' whose stories are constantly co-opted by 'the center' (even if these people are part of the same national historiography), and the second with regard to the ecology and life-worlds in Ro, appreciated by some but not by others, as we discuss below.

\section{Developing islandography}

To refer to islandography is to seriously engage the study of islands, to explore them as spaces which have been created not solely through natural phenomena, nor solely as political constructs of history. It is to explore how such spaces have also been affected by social imaginaries and projections. To that extent, islandography approaches islands as social spaces in Lefebvrian terms (rather than solely ecological or national/political spaces), and how they have been produced and reproduced. As Lefebvre (1991, p. 77) put forward, "a social space cannot be adequately accounted for either by nature (climate, site) or by its previous history." Building up from the previous section and the exploration of how island histories can be decolonized, this section now turns towards an attempt to link these social histories with space, as that process of reclaiming island histories and cultures (Baldacchino, 2008). How and why have specific island histories been written, by whom and what for? To explore these questions, one needs to explore how these histories constructed the island space, but also the other way around; what was the role of the particular island space in the writing of these histories?

An attempt to recalibrate the concept of islandography requires an interdisciplinary engagement in space and time. The concept of islandography itself was put forward by Raine Edward Bennett (1971, p. 39) to describe the newly found interest about islands defining it as "all verifiable general knowledge must be applicable to each island as a 'geographic personality' in its own special environment." Yet the concept of islandography never really left the ground. It is oceanography, as the study of the physical and biological aspects of the ocean, that has become a major academic field in natural sciences. Moreover, nissology, as "the study of islands on their own terms; the open and free inquiry into island-ness; and the proportion of international cooperation and networking amongst islands" (McCall, 1994, p. 105) has become the main field of studying islands, whether as natural or social constructs. From our perspective, islandography is not about the mere exploration into islandness (i.e., the use of nissology). It is rather an appreciation of islands as scripted sites and complex social spaces. Islandography is never simply about trying to understand what an island is, but rather about understanding how to engage rival island histories, the practice of history writing, and the contextualization of the geographic location. 
In developing islandographies, it is important to appreciate that islands often operate as zones of exception, as sites of creative governance and innovative jurisdiction (Baldacchino, 2010). Their geographic separateness allows for territorial zonings that take exceptions from traditional forms of sovereign rule. The isolation of some islands suggests that certain types of people are sent there, and/or certain types of people decide to go there. Their ecology depends on their isolation as well as their proximity to other lands. All these compose an island's 'geographic personality'. Furthermore, developments with regard to their status following the 1982 United Nations Convention on the Law of the Sea (UNCLOS) have redefined and upgraded their importance, especially those that are furthest away from the mainland or at the edge of an archipelago. Islands that 'can sustain human habitation or economic life of their own', no matter how small they are, can claim up to 200 nautical miles of Exclusive Economic Zone and 350 nautical miles Continental Shelf (UNCLOS, Article 121), which is why they have been suggested to be accelerators of the territorialisation of marine space (Fleury, 2013). In other words, islands can now be a springboard for exercising new forms of oceanic sovereignty and extensive marine appropriation. Especially in islands that are contested or in the midst of contested sea claims, not only the national identity of islands, but the presence of human habitation and economic activity is very much a concern of modern governance and national historiography. This also needs to be invariably performed on the basis of national policy claims and/or rival counterclaims.

The national grand narrative and the specific island history inevitably intersect and occasionally clash. National historiography seeks to co-opt island history, translating island life into (heroic) nation biography. As Harvey (1982, p. 390) talks about islands of locational advantage which can be produced through an "active moment" of capitalism, border islands can be produced through an "active moment of nationalism." Using the case of the island of Ro, the story of which became scripted in a certain way after 1974, we develop the notion of decolonial islandography, which exposes "the wilful or wishful historical amnesia" (Grydehøj, 2017, p. 9) that accompanies hegemonic historiography and retrieves other histories that are made invisible once this 'moment' becomes activated.

A number of studies have deliberated over island ontology. In terms of islands as natural creations, Lasserre (1987) stated that defining an island through the eyes of a biologist is simple: islands exist and they build a separate world which is of great ecological value; a discussion which goes back to MacArthur and Wilson's Theory of Island Biogeography, published in 1967, which "mark[ed] a true turning point in the advance of ecological science, and thence in our understanding of how the natural world works" (May, 2010, p. ix). Dodds and Royle (2003), taking on a critical geopolitical view, suggest that islands, viewed as an abstract territorial space, can be used to construct complex political stories, linked to their history and geography (see also Jędrusik, 2011; Stephens, 2013). Following the above scholarly work, this article wants to move beyond this understanding of how islands construct national histories, to how islands and their histories not only become hidden, but how they are reclaimed by users, who exploit or re-appropriate their dominant projection. Another important aspect is the cultural dimension of islands (Suwa, 2007) such as, for example, the way islands can denote social groupings and how cultural interactions and performances of demarcation can enact a territorial imagination, creating a 'cultural landscape' for the population and visitors of an island. 


\section{Imagining Ro: within and beyond national historiography}

The Kastellorizo complex, including Ro, came under Ottoman Rule in the 16th century. It was given various privileges in return to its submission, such as the right to maintain the local language, religion and traditions (B $\alpha \rho \delta \alpha \mu$ í $\delta o v, 1948$, pp. 49-57). In the mid-19th century, the High Porte gave some additional privileges to the inhabitants of Kastellorizo, such as exemption from annual taxes, free movement, and self-government, which meant that it flourished economically. Its merchant fleet became powerful in the Mediterranean in the beginning of the 20th century and the islanders, numbering around twelve thousand at that

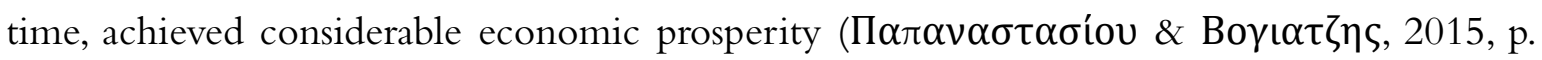
25). The adjacent islets surrounding Megisti/Kastellorizo, such as Ro and Strongili, were not developed and only periodically inhabited by fishermen, goat herders, and beekeepers. With the Paris Peace Treaties, Kastellorizo was assigned to Greece in 1947 and the island formally joined the Greek State on the 7th of March, 1948, along with the rest of the Dodecanese

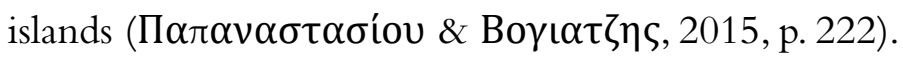

The above is a typical historical introduction of the island region as provided from written academic and popular sources. It forms part of the story, the focus of which is geographical position and history, which has created an image of Ro as an island of national importance. Below we combine these historical data with insights we gained from interviews as well as literary works on the Lady of Ro.

\section{The making and remaking of the Lady of Ro}

The history of the Kastellorizo complex, and particularly of the islet of Ro holds a special reference to the Lady of Ro, the woman who, as the national story goes, raised the Greek flag over Ro during World War II and while Katellorizo was not formally part of Greece but of Italy. She also continued during the period when the whole of Kastellorizo was evacuated by the British and she was literally left by herself on Ro, taking care of her elderly blind mother that moved there. She continued to raise the Greek flag after Kastellorizo joined Greece and contra claims made by Turkey over the surrounding uninhabited or sparsely habited islets. The life story of this solitary woman has been glorified in Greek national historiography and it has helped to brand both Ro and Kastellorizo as islands of defiance and resistance. The austere looking bust of the Lady of Ro dominates over Megisti square, and one can buy small statuettes, posters, and postcards in the souvenir shop. She has become the embodiment of an island trying to keep its national identity at the 'edge of territory'.

The life of Despoina Achladioti (the actual name of the Lady of Ro) on the islet goes back to 1927, when she moved there with her husband Costas after winning a public auction to use Ro as a pasture for their goats. There are different versions of the story as to why the couple decided to live 'in exile'. The story of a 'forbidden love' between the poor shepherd (Costas) and the daughter of a wealthy family (Despoina) is one of the favorite versions for documentaries and magazine/newspaper articles. This story, however, is not confirmed by the current residents of Kastellorizo.

The couple lived a quiet and lonely life in Ro. They took care of their flock, Despoina would make cheese, and they would travel to Kastellorizo every week to sell their produce. References regarding the first 'Turkish provocations' go back to 1929 with the rising of the 
Turkish flag on the islet. Apparently, the couple took down the flag as soon as they realized and informed the authorities of Kastellorizo. In 1940, Costas fell seriously sick. Despoina tried to light a fire to call for help, but help came too late and Costas died on the small boat on the way to Kastellorizo. Following the death of her husband, Despoina continued her life on the islet with the company of her blind mother, who also passed away a few years later. She continued to live on the island on her own, though there is inconsistency as to whether she moved to Kastellorizo when she got older, or whether she really did stay on the islet, raising the Greek flag until her death in 1982.

The stories around the life of the Lady of Ro are multiple and sometimes conflicting. Undoubtedly, life on the islet was hard and lonely. As she fit the perfect profile for a heroine, she is often compared to one of those Greek heroines from 1821, such as Bouboulina. The point of reference which made Despoina part of the Greek national historiography was a publicized act by Omar Kasar, a Turkish journalist, and two others, who took a boat to the island of Ro in August 1975 and rose the Turkish flag. According to this story, Despoina was in Kastellorizo at the time for medical reasons, which gave the "Turkish side" an opportunity. This event reproduced the islet as an "active moment" of national struggle, signaling the mythography of the Lady of Ro and her becoming part of the national historiography. She became a national celebrity, following an interview she gave to one of the most famous Greek TV personas Freddy Germanos back in 1982 as well as the award she was given by the Greek State for her act of patriotism (EPT A.E., 2013).

Lady of Ro as a flag-raiser/border keeper became an entrenched image of Greek national resistance. "Each day, facing Turkey - which was within easy eyesight - she would raise the Greek flag and pull it down at sunset, whatever the weather. She did it until her death in 1982 aged 89" (Williams, 2004). Retired Greek Admiral Michael Agapitos, a Kastellorizian who knew the Lady of Ro well, was instrumental in the construction of the story of the Lady of Ro. According to him, "to Greeks, she was a Joan of Arc or Boadicea-like figure whose weapon was just a fluttering Greek flag, not a sword" (Williams, 2004). She was linked to earlier national heroes like Lambros Katsonis, who is known to have used the fortress at Ro as his base of operations during the Ottoman rule (1788-1792). The transhistorical connection of these two heroic figures underscores the continuity of the Hellenic identity of the islet and of Ro as a national symbol.

During our visit to Kastellorizo, it became obvious, however, that there was not one agreed version of her story, her life, nor her personality. From the interviews we held, for most of the locals she was closer to an everyday island woman, struggling to make a living, displaying perseverance and resilience. On the one hand, we heard comments which praised the bravery of Despoina living alone on an islet 'opposite the Turks', and on the other we were told stories about her links with the 'opposite side', to whom she was often selling her products. This is, of course, part of a wider discussion regarding the relations between the people of Kastellorizo with the people of Kaş across the water. It was interesting to hear Despoina, when offered by Freddy Germanos "kattimeri, their [Kastellorizo] local/national dessert" during the interview she gave back in 1982, commenting that "yes, it is Turkish," making the presenter uncomfortable for his mistake (EPT A.E., 2013).

Despite the visual commemoration of heroism, our discussions with the locals actually weakened, rather than reinforced, the argument of Despoina's flag-raising past. During a 
conversation with one of the older Kastellorizian women, who as a young child remembered Despoina, she described that during the day the Lady of Ro was given an award by the Greek State, there were some Kastellorizian women who were probing her ironically by saying, "When did you raise the flag? You never raised a flag! Why are they giving you an award?!" There were also stories suggesting that Despoina, as part of her methodology for resilience and survival, didn't only raise the Greek flag, but that she rather raised various flags, or the flag of whatever ship passed by in order to lure visitors. Whilst the questioning of the Lady of Ro as a flag-raiser was evident when at Kastellorizo, this was juxtaposed with both the visual reality of being on the island, as well as the dominant narrative about the island. The local historiography carefully existed alongside the national grand narrative, something which appeared to be very important for Kastellorizians who were careful as to not fully deconstruct this famous aspect of their island and place branding. A non-Kastellorizian actress who played Despoina in a recent monologue theatre, though she was ready to defend the truth behind the story about the Lady of Ro, commented that "one should not try to demystify heroes; there is a reason they become one."

Following the Imia incident in 1996, after which a number of Greek border islets became visibly militarized, Ro was also visually reconstructed to fit the image of an island, the identity of which was kept Greek through heroic sacrifices. Ro thus became a site of pilgrimage for Ministers, Members of Parliament, etc., at times of national crises, particularly during times when it was felt that the Greek islands' sovereignty was threatened by Turkey. Among different examples, in December 2018, following flights of Turkish F-16 military planes over Greek airspace in the Aegean, the then Greek Minister of National Defence, Panos Kammenos, along with representatives from the Greek Armed Forces and the Hellenic Navy, visited Ro. During the visit, he stated that:

Our presence here is an opportunity to pass the message to our neighbours, that this country will remain faithful to the ideals of its ancestors, who were the first to put the foundations of democracy and offer it to the world. We also want to remind them that we are a peaceful country that nonetheless demands to be respected, as it respects others. Whoever will not respect our national sovereignty and our territorial integrity will be crashed. We are determined to defend our country, to defend our altars and our homes (BriefTeam, 2018).

In 2014, a similar statement was made by Nikos Dendias, who was again visiting Ro as the Greek Minister of National Defence. As quoted in an online newspaper:

Both the Ministry of National Defence and, above all, the Greek State as a whole will support the people who hold the national morale as well as the Greek flag high at the edge of Greek territory ... and [want to remind our neighbours], that though Greece has the honour to be at peace with all peoples, it is also absolutely determined to uphold both its national sovereignty and its national dignity (thePAPER.gr, 2014).

According to the same article, Dendias then turned to the people of Kastellorizo, saying that they are living proof of the country's determination to defend its national sovereignty as well as its national dignity. 
In terms of the pluralization of the 'Lady of Ro' narrative, a recent theatrical play with the same exact title that toured the entire Greece, including Kastellorizo, as well as Australia and the USA, provides a highly interesting addition. The theatrical play written by Yiannis Skaragkas (2017) is a monologue, a poetic re-enactment of the solitary woman, inspired by both the history and the myth of the Lady of Ro. As the playwright puts it in the blurb of the play: "A secluded woman raises and lowers a flag to narrate the sufferings of the people she loved, their mistakes and their wounds... It is a tragic hymn to life through the eyes of a woman that

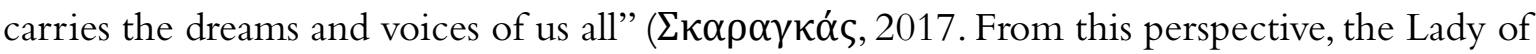
Ro has "many homelands" beyond Greece that she "wish[es] to talk about" ( $\Sigma \kappa \alpha \rho \alpha \gamma \kappa \alpha \dot{s}, 2017$, pp. 77-78). And in these 'poetic' homelands, the social and personal history of the woman fully unfolds and is given symbolic recognition: e.g., the smell of her mother, the embrace and breaths of her husband, the Easter celebration with one's beloveds - that is her homeland.

What about the raising of Greek flag that the Lady of Ro is quintessentially known for? The play meditates on the meaning of raising 'the flag'. But it contrasts the political flag to the social-personal flag in the way it poetically envisions, for example, the bride's and groom's clothes as a different flag - given that these clothes were hanged in Kastellorizo's trees before the wedding just like a flag. As opposed to the national flag that demands the heroic sacrifice, the hanged clothes of the wedding celebration "looked like the flags of a country that wants

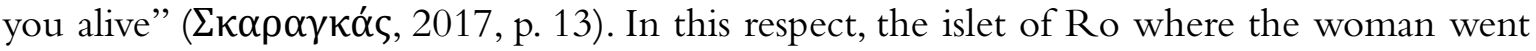
to live with her husband is not viewed by the protagonist as a deserted place, a space of social isolation. Her perspective opens an insight into the ecology of the island and the more-thanhuman sociability that is possible there.

The islet, Ro, looked like a kingdom. A dry lemonskin surrounded by blue. Myself, my husband and the blue. This was our people. Perhaps it had no voice, but it changed colours, countless colours and faces, according to the seasons and the days

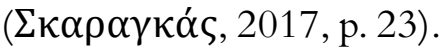

Beyond the pluralization of the homeland, which has been characteristic of more heterodox approaches that variably aestheticized the Hellenic nation (Constantinou, 2006), what we see in the Lady of Ro play is an attempt to regain the homeland for the solitary human and the biodiverse subjects that inhabit it.

Yet, to know one's island and live a 'solitary' life in it, should not disempower one from speaking about the world. The theatrical Lady of Ro protests how travellers tell her that she needs to travel herself to know about the world. She rejects their notion that 'her knowledge of the world' is inferior to theirs. 'Her world' has meaning for her but should also be valued for what it can teach others about their own worlds. "For the life of the last wretched of the earth should count, for one can also understand from the stone, the wild fig tree and the wind" ( $\kappa \kappa \alpha \rho \alpha \gamma \kappa \alpha ́ \varsigma, 2017$, p. 48). Beyond an alternative islandography, this other Lady of Ro underscores the value of 'poor theory', the bare theory stripped off epistemological and scholastic excesses, displaying what Ngũgĩ wa Thiong'o (2014, pp. 15-28) calls "globalectics," equalizing distant places and diverse viewpoints, bringing a "mutually affecting dialogue" from any vantage point in the world. 
An island of one's own

The political historiography of the island is that which has become part of the dominant narrative and has produced the national identity of the islet as we know it today. Whilst on Kastellorizo, we had the opportunity to hear about alternative stories, and follow other personal cartographies of the islet. Some of these cartographies transformed our understanding as well as our appreciation of the island, whilst others are mere reproductions or, rather, attempts to reproduce a nationalist cartography such as that of the Lady of Ro. Factors such as the geographical position, the isolation, as well as its use as a grazing ground are important aspects in all historiographies of Ro, but sometimes given different meanings.

Following the death of Despoina, the islet remained uninhabited by humans, with only the shepherd who leased the islet for grazing visiting the islet approximately once a week to check, feed, and water the animals, as well as the fishers who would find shelter on the island if needed. This was until 1992, when the islet became the temporary home of a rather unusual couple for the conservative island of Kastellorizo. Houlis, a Kastellorizian communist fisherman, and Loeke, a Dutch teacher/artist, a child of the 60s who ended up on Kastellorizo during her search for faraway islands. Houlis' love for alcohol was causing him serious health issues and he was prompted to stop drinking by his doctor. As this would have been difficult to achieve on Kastellorizo, a shepherd suggested the islet to the couple.

According to Loeke, they lived through beautiful times on the islet, being self-sustainable as much as they could. During our visit, she stated "all my life I've wanted to live on a small island and learn how to survive." It was indeed the case that Kastellorizians described Loeke as a 'saint' for her willingness to live on Ro in order to help Houlis stop drinking. She herself, however, could not understand this description; “They don't realise that I loved it!" They fished for themselves, foraged, and they also had friends who were visiting them with food from Kastellorizo as well as the Turkish town of Kaş across the water. The couple had no national ambitions, but rather enjoyed the solitude the islet offered, the nature, and each other. Loeke also spoke to us with fondness of Yamour, a bull brought from Turkey for the reproduction of the cows on the island who, however, became domesticated and fell in love with Loeke, and she with him - becoming thus a pet instead of a farmed animal. There were also visited by famous people at times; of particular reference was the visit and performance by Nana Mouschouri and Manos Hadjidakis, who arrived on Ro via helicopter from Kastellorizo,.

For Loeke and Houlis, life in Ro meant freedom. A space imagined by others as a space for exile, for Loeke, it was a blessed space to live. Loeke and Houlis reclaimed an aspect of the island which was at best ignored, and at worst vilified or glorified; its natural elements, its solitude, and its 'dangerous proximity' to Turkey. By contrast to the tomb of the Lady of Ro, the grave of Houlis in Kastellorizo, who died in 2011, features a social and personal history that is only meaningful to his loved ones and those who knew him. The return of Loeke, following the establishment of an army unit on the islet, was a very different experience, as being free to roam on 'her island' became forbidden by the army. She has refused to return to Ro since, as its identity had totally changed.

After Loeke and Houlis returned to Kastellorizo, the islet of Ro became the host of three individuals. Klimis Nauridis, a physiotherapist from Athens, apparently moved to Ro in 1993 following a divorce from his wife with the aim of continuing the role of Despoina Achladioti. According to a blog written by people who passed by Ro and met him, Klimis received a Greek flag from the Mayor of Rhodes (after his own request) and a small barrel of 
benzene per month from the Greek navy for his dingy which he used to move around

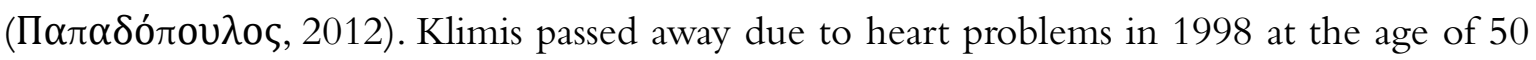
and thus there is limited information about his experience on the islet through his own eyes.

Soon after he moved on the island, Klimis was joined by two other men, Ioannis Alexakis and a photographer, with whom there was tension. The role of the three men on the island is ambiguous and the people of Kastellorizo appear to have a rather suspicious view regarding the reasons for the men's presence. It seems that the three men quarrelled and that was the reason that they all left the island. We had the chance to interview Ioannis Alexakis, a self-

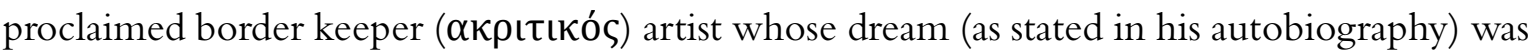
to live on the island of Ro and create a nautical museum with the artefacts he collected over the years. Alexakis put forward that this was an idea suggested to him by the famous Greek actress, singer and politician Melina Merkouri, in 1993. In his autobiography (A $\lambda \varepsilon \xi \dot{\alpha} \kappa \eta \varsigma, 2013$ ), titled The Lord of Ro (an appropriation of the female version given to the Lady of Ro), and particularly in the chapter "Citizen of Ro," Alexakis describes his feelings about the islet. He states that for two years, he kept returning to the islet, where he would stay for periods of over two, three, and even six months. There, he states:

serenity, loneliness, abandonment, but also thought itself, offer through different touches an alternative colour to what the word country means.... On that deserted place, I found the opportunity to understand myself. I found the solitude that I needed. I sucked on the great moments of meditation and serenity it offered. Upon these foundations, releasing myself from the voracious fury of time, I put myself at the service of $\operatorname{art}\left(\mathrm{A} \lambda \varepsilon \xi^{\prime} \alpha \dot{\kappa} \eta \varsigma, 2013\right.$, p. 28).

Alexakis imagined himself as having a national as well as a cultural mission in Ro. During our interview, he suggested that at least he "was able to offer to the place," vis-à-vis "the lady who liked ecology." He imagined himself as 'borderline artist', who nevertheless needed a border island to establish himself on. Ro, therefore, was the materialization of that imaginary, and the fact that his plans did not succeed left him feeling bitter.

Following the departure of the three men, the islet became a military camp for a small unit. Lives of soldiers must be particularly difficult as they are turned into the continuators of the legacy of the Lady of Ro, whilst visitors on the islet continue to 'enjoy' the pilgrimage to the Lady's tomb and the spectacle of the islet on the borderscape.

\section{Reimagining Ro: towards a politics of islandography}

Island histories, just like stories and histories in general, can be told in manifold ways. This article discussed and presented how the small and isolated islet of Ro has become a national symbol and what this meant for the alternative histories which became sidelined in the process. Through grand national narratives to the histories of the subjugated and the subaltern, and other life-worlds, which are made known and visible following careful consideration and more targeted research, we discussed the alternative islandography that is hidden under the hagiography of the Lady of Ro. 
These stories which emerged from the borderscape indicate that island stories are inextricably linked with contested political, social, cultural, and personal imaginaries which, when combined, can bring out an island's 'geographic personality'. The 'active moment' which signified the appropriation of past and future local histories through the construction of a grand narrative was, in the case of Ro, a publicized attempt to raise a Turkish flag on the islet. The Greek nation found then a hero in the face of Despoina Achladioti, a person who until then had a very difficult and lonely life. The lives of the others who passed from the island following the death of the Lady of Ro, the alternative meanings each of them invested on the islet, and the alternative valorizations highlight the importance of vernacular mapping, not as a mere means of fixing spatial relations and geopolitical identities of official cartographies, but as a process of producing, contesting, and transforming the story and identity of islands. The size and the isolation of Ro indicates that uninhabited islands become a site of contestation between different actors for whom these spaces have different meanings and uses. This also relates to the personalities of the people who chose such islands in the first place. From Despoina and Costas, to Loeke and Houlis, and then to Klimis, Ioannis Alexakis and the photographer, the island means very different things to different people; an isolated workplace, heaven on earth, proof of patriotism, as well as posthumous fame.

Today, Ro remains a militarized space, known and described as the 'extremity' ( $\varepsilon \sigma \chi \alpha \tau \iota \alpha$ ) of Greece. Essentialized as the border keeper, the lives of the young soldiers sent to serve their military service on Ro are reduced and pale under the shadow of the 'Lady of Ro'. Only a few days before our second visit to the island, in July 2018, we read about the suicide of a young soldier who was doing his service on the islet. The lives of these 'others' sometimes become visible when the national borders are threatened, which is when Ministers and Parliamentarians pay visits as a show of respect as well as to gain publicity. Life at the border could not be left without 'James Bond' type stories, most recently of women in bikinis spying on the islet of Ro (New Post, 2014). Though the multiple lives of the human and the nonhuman passings have been over-shadowed by the importance given on the islet as a borderkeeper, this does not stop this particular space from the continuous production of other stories and imaginings. For retrieving such stories, one requires to become immersed in the islet's everydayness. It is only then that one can explore how local life is being or has been affected by the way the knowledge of the islet has been produced and re-produced. Though there is often a political hegemony which determines the dominant story of an island, this article has shown that studying islandographies opens up possibilities for new knowledge as well as praxis. Perhaps it also offers a sort of justice, giving due thought to the fragility of lives and their stories which have been sidelined on the way. 


\section{Acknowledgments}

The research for this paper was made possible through University of Cyprus internal research funds for the project 'The Diplomacy of the Borderscape: Negotiating Security, Ecology and Identity at the Limits of Territory'. We are grateful to the inhabitants of the Kastellorizo island, and to all those who agreed to be interviewed in the framework of the project. We presented an earlier version of this paper at the workshop on 'The Diplomacy of the Borderscape', organized at the University of Cyprus, 26-27 July 2018. For their feedback, we would like to thank the participants at the workshop, Constantinos Adamides, Pinar Bilgin, Sharon Cheong, James Sidaway, Nicos Trimikliniotis, and Demetris Trimithiotis, as well as two anonymous reviewers.

\section{References}

Anderson, B. (1983). Imagined communities: Reflections on the origin and spread of nationalism. Verso. Balasopoulos, A. (2008). Nesologies: Island form and postcolonial geopoetics. Postcolonial Studies, 11(1), 9-26. https://doi.org/10.1080/13688790801971555

Baldacchino, G. (2010). Island enclaves: Offshoring strategies, creative governance, and subnational island jurisdictions. McGill-Queen's University Press. https://doi.org/10.1177/1474474013478369

Baldacchino, G. (2008). Studying islands: On whose terms? Some epistemological and methodological challenges to the pursuit of island studies. Island Studies Journal, 3(1), 37-56.

Bennett, R. (1971). Islandography - New study. Oceans, 4(2), 34-40.

Bożętka, B. (2013). Wolin Island, tourism and conceptions of identity. Journal of Marine and Island Cultures, 2(1), 1-12. https://doi.org/10.1016/j.imic.2013.03.001

Chakrabarty, D. (2000). Provincializing Europe: Postcolonial thought and historical difference. Princeton University Press. https://doi.org/10.1086/ahr/106.4.1322

Chatterjee, P. (1993). The nation and its fragments: Colonial and postcolonial histories. Princeton University Press.

Cohn, B.S. (1996). Colonialism and its forms of knowledge: The British in India. Princeton University Press.

Constantinou, C.M. (2006). The beautiful nation: Reflections on the aesthetics of Hellenism. Alternatives, 31(1), 53-75. https://doi.org/10.1177/030437540603100103

Dodds, K., \& Royle, S.A. (2003). The historical geography of islands Introduction: Rethinking islands. Journal of Historical Geography, 29(4), 487-498. https://doi.org/10.1006/jhge.2002.0406

Fleury, C. (2013). The Island/sea/territory. Towards a broader and three dimensional view of the Aquapelagic Assemblage. Shima, 7(1), 1-13.

Gibbons, M.S. (2010). Islanders in community: Identity negotiation through sites of conflict and transcripts of power. Island Studies Journal, 5(2), 165-192.

Gillis, J.R. (2001). Places remote and islanded. Michigan Quarterly Review, 40(1), 39-58.

Gray R., \& Sheikh, S. (2018). The wretched earth: Botanical conflicts and artistic interventions. Third Text, 32(2-3), 163-175. https://doi.org/10.1080/09528822.2018.1483881

Grydehøj, A. (2017). A future of island studies. Island Studies Journal, 12(1), 3-16.

Harvey, D. (1982). The limits to capital. Basil Blackwell. 
Hawthorne, S. (2008). Wild politics: Feminism, globalisation, bio/diversity. Aakar.

Jędrusik, M. (2011). Island studies. Island geography. But what is an island? Miscellanea Geographica-Regional Studies on Development, 15(1), 201-212. https://doi.org/10.2478/v10288-012-0012-7

Lasserre, G. (1987). Le géographe et les îles. In Iles tropicales: Insulairité, “insularisme” (pp. 16). Presses Universitaires de Bordeaux.

Lefebvre, H. (1991). The production of space. Blackwell.

May, R. (2010). Foreword. In, Losos, J.B., \& Ricklefs, R.E. (Eds.). (2010). The theory of island biogeography revisited. Princeton University Press. https://doi.org/10.1515/9781400831920.vii

Mbembe, A. (2001). On the postcolony. University of California Press.

McCall, G. (1994). Nissology: A proposal for consideration. Journal of the Pacific Society, 17(23), 93-106.

Morris, R. (Ed.). (2010). Can the subaltern speak? Reflections on the history of an idea. Columbia University Press.

Nicholson, A. (2007). The islands. Geographical Review, 97(2), 153-164.

Opondo, S.O. (2015). Biocolonial and racial entanglements: Immunity, community, and superfluity in the name of humanity. Alternatives: Global, Local, Political, 40(2), 115132. https://doi.org/10.1177/0304375415589432

Pieterse, J.N., \& Parekh, B. (Eds). (1995). The decolonization of imagination: culture, knowledge and power. Zed.

Smith, L.T. (2013). Decolonizing methodologies: Research and indigenous peoples. Zed.

Spivak, G.C. (1999). A critique of postcolonial reason. Harvard University Press.

Stephens, M. (2013). What is an island? Caribbean studies and the contemporary visual artist. Small Axe, 17(2), 8-26. https://doi.org/10.1215/07990537-2323292

Suwa, J.I. (2007). The space of Shima. Shima, 1(1), 6-14.

Trinidad, J. (2018). Self-determination in disputed colonial territories. Cambridge University Press. wa Thiong'o, N. (2014). Globalectics: Theory and the politics of knowing. Columbia University Press.

wa Thiong'o, N. (1992). Decolonising the mind: The politics of language in African literature. East African Publishers.

Williams, B. (2004, November 10). The Lady of Ro's memory lives on. Ekathimerini. Retrieved from http://www.ekathimerini.com/27152/article/ekathimerini/news/the-lady-ofros-memory-lives-on

\section{Greek References}

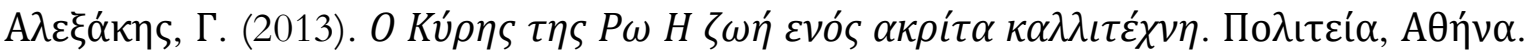

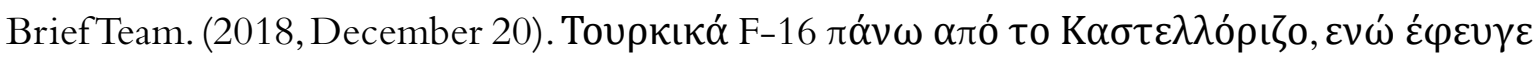

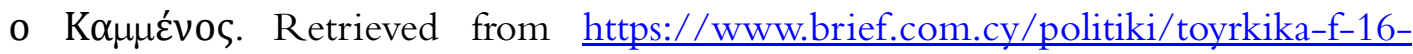
pano-apo-kastellorizo-eno-efeyge-o-kammenos

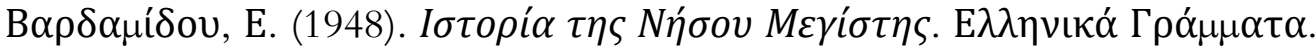

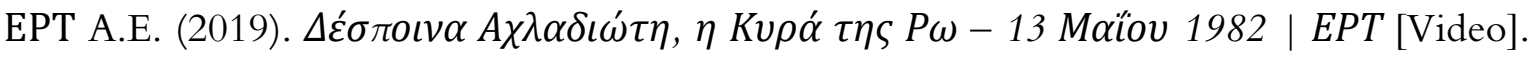

Retrieved from https://www.youtube.com/watch?v $=$ wtlKHBILTO0 


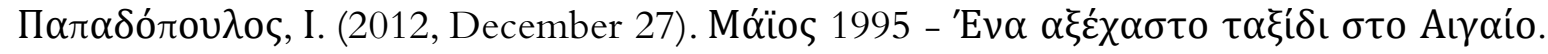
Retrieved from https://www.ribandsea.com/memo/847-1995.html

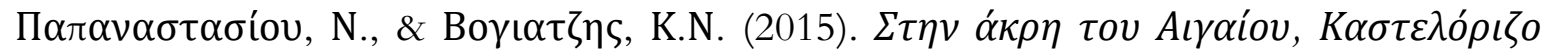

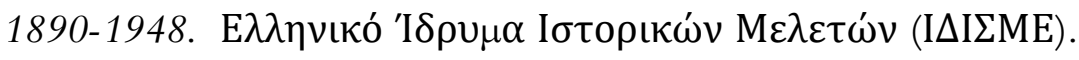

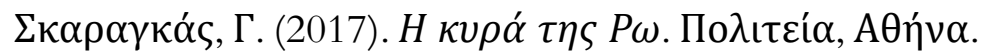

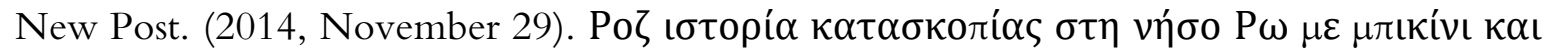
$\theta \alpha \lambda \alpha \mu \eta \gamma$ ó! Retrieved from https://newpost.gr/post/402657/roz-istoria-kataskopiassth-nhso-rw-me-mpikini-kai-thalamhgo

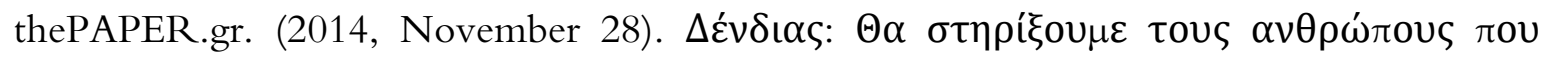

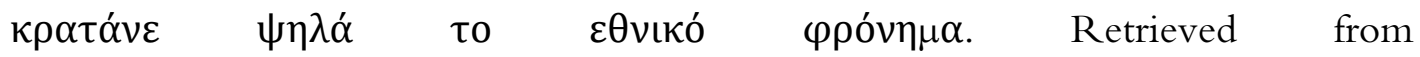
http://www.thepaper.gr/dendias-tha-stirixoume-tous-anthropous-pou-kratanepsila-to-ethniko-fronima 